\title{
The Optics Institute of Southern California: organizing and implementing outreach effort
}

\section{Donn Silberman}

Donn M. Silberman, "The Optics Institute of Southern California: organizing and implementing outreach effort," Proc. SPIE 9663, Eighth International Topical Meeting on Education and Training in Optics and Photonics, 96631 K (6 October 2003); doi: 10.1117/12.2208468

SPIE Event: Eighth International Topical Meeting on Education and Training in Optics and Photonics, 2003, Tucson, Arizona, United States 


\title{
The Optics Institute of Southern California, organizing and implementing the outreach effort
}

\author{
Donn M. Silberman \\ The Optics Institute of Southern California \\ 31 Blackbird Lane, Aliso Viejo, CA 92656 \\ tel: 949-581-5185,fax: 949-581-0123,e-mail:Donn@oisc.net
}

\begin{abstract}
The Optics Institute of Southern California is organizing the local educational outreach effort. Working with local optics businesses, society chapters, science discovery centers, K-12, community college and university educators, and others from the global optics education and training community, the OISC is becoming a one-stop clearing house for a wide range of educational outreach activities.

(C)2003 Optical Society of America
\end{abstract}

OCIS codes: (000.2060) Education; (000.1200) Announcements, awards, news, and organizational activities

\section{Summary}

This paper describes the recent and some proposed future activities of The Optics Institute of Southern California (OISC) that has been incorporated as a 501 (c) (3) not for profit corporation in the State of California by the author and a Board of Directors in a direct response to the following conditions:

- The local education community does not have formal or informal science curriculum that is organized to teach the basics of optics and photonics technologies.

- The local scientific and industrial communities continue to require people at least knowledgeable and at best fully trained to participate in the continued development of optics and photonic technologies as they support a broad spectrum of critical industries including: aerospace, defense and homeland security, biomedical, telecommunications, transportation, commerce, entertainment and energy.

As a result of these conditions, the OISC is acting as a local organizing and implementing agent to provide services to teachers, educators and trainers who wish to use developed tools and resources to improve the knowledge and readiness of students in K-12 and community colleges, and to help small businesses.

\section{Mission}

- Use optics as a vehicle to make science and technology interesting and accessible to people in Southern California.

- Bring optics presentations, demonstrations and follow-up classroom 'hands-on' materials to K-12 Students and Teachers in Southern California.

- Encourage students to include the study of optics in college and provide paths for them to follow.

- Provide training for people who work in companies that use optics in their products and services.

- Work with Southern California companies to implement optics in their products and services.

\section{Purpose}

As clearly stated in the "Optics Education - A Blueprint for the 21st Century" A project of the Optical Society of America and SPIE - The International Society for Optical Engineering - December 2001"; there exists specifically identified barriers to teaching optics in the K-12 grades and that has created a void in filling the demand for trained people in the optics industry.

The main purpose of The Optics Institute of Southern California is to provide a vehicle to break through some of those barriers and clarify the role of optics in the lives of teachers and students and create the potential for students to pursue / include optics as part of their college studies and then career choices. 
OISC's success in this purpose will benefit the optics industry and its role in many other industries by acting as a model for others around the world. This will lead to ensuring that the future demands for trained people in all levels of the optics industries will be met.

Proc. of SPIE Vol. $966396631 \mathrm{~K}-2$

Downloaded From: https://www.spiedigitallibrary.org/conference-proceedings-of-spie on 26 Apr 2023 Terms of Use: https://www.spiedigitallibrary.org/terms-of-use 